\title{
PENGAKUAN PENDAPATAN DAN BIAYA BERDASARKAN STANDAR AKUNTANSI KEUANGAN PADA RUMAH SAKIT UMUM PUSAT WAHIDIN SUDIROHUSODO DI MAKASSAR
}

\author{
DIGOR MUFTI \\ Universitas Muhammadiyah Sorong \\ widyadigormufti27@gmail.com
}

\begin{abstract}
The purpose of this research is to acknowledge the income recognition and the cost of Wahidin Sudirohusodo Centre General Hospital, Makassar. This research applied qualitative data and comparative analysis methods by counting the data recorded in the financial statement and activity report. It is found that the recognition of income and costs has met the PSAK Number 23 where it means it also has satisfied the financial accounting standard's guidance. Financial report has qualified opinion dated on December 31, 2017 along with financial performance and cash flow.
\end{abstract}

Keywords: Income, Cost, Accounting Standards, Accounting

Abstrak: Tujuan penelitian ini adalah untuk mengetahui pengakuan pendapatan dan biaya yang terdapat pada Rumah Sakit Umum Pusat (RSUP) Wahidin Sudirohusodo Makassar. Metode analisis komparatif di aplikasikan untuk mengolah data kualitatif, secara spesifik dilakukan penghitungan angka yang terdapat pada laporan keuangan dan aktivitas. Dalam penelitian ini, ditemukan bahwa pengakuan pendapatan dan biaya telah mengikuti pedoman PSAK Nomor 23 yang berarti bahwa laporan keuangan RSUP Wahidin Sudirohusodo telah sesuai dengan standar akuntansi keuangan (SAK). Laporan keuangan menyajikan secara wajar laporan keuangan per tanggal 31 Desember 2017 beserta kinerja keuangan dan arus kas. Hal ini telah sesuai dengan Standar Akuntansi Keuangan.

Kata kunci: Pendapatan, Biaya, Standar Akuntansi, Akuntansi

\section{PENDAHULUAN}

Organisasi laba yang memberikan layanan dalam bidang Kesehatan adalah rumah sakit. Salah satu sumber pendapatannya berasal dari sumbangan anggota dan lainnya. Menjaga kinerja laporan keuangan dilakukan dengan mengukur jumlah dan kepastian aliran pendapatan. Dalam berbagai macam literatur di bidang akuntansi, pendapatan dikorelasikan dengan cara mendapatkan dan mengukur pendapatan tersebut. Perolehan pendapatan dapat terjadi secara terus menerus atau pada waktu waktu tertentu.

Perusahaan menerima pendapatan dalam berbagai sumber ekonomi yang berasal dari transaksi penjualan barang dan pemberian jasa kepada pihak lain (Harmanto, 2010:14) dimana telah terjadi penjualan atau penyerahan jasa. Menurut Bardiwan (2012:30), pendapatan merupakan aktiva masuk serta kenaikan lain aktiva dari suatu badan atau pelunasan hutang salama kurun waktu tertentu yang berasal dari penyerahan atau produksi barang, penyerahan jasa atau kegiatan lain yang merupakan bagian dari aktifitas bisnis utama badan usaha.

Dengan kata lain, pendapatan merupakan total penerimaan dari jumlah total penjualan barangbarang jasa dari unit usaha selama periode tertentu. Dalam Pedoman Standar Akuntansi Keuangan (PSAK) Nomor 23 (2002:23.3), Ikatan Akuntansi Indonesia (IKA) menyebutkan bahwa pendapatan merupakan arus masuk bruto dari manfaat ekonomi karena adanya aktivitas normal perusahaan dalam 
periode waktu tertentu apabila arus masuk itu mengakibatkan kenaikan ekuitas, yang tidak berasal dari kontribusi penanaman modal.

Kam Vemon (2010:137) memberikan penjelasan bahwa pendapatan adalah aliran masuk atau peningkatan jumlah aktiva atau penyelesaian kewajiban dari suatu perusahaan selama suatu periode dari penyerahan atau produksi barang, penyerahan jasa atau aktivitas lainnya yang berhubungan dengan operasi utama perusahaan.

Keiso (2013:696) menyatakan bahwa pendapatan adalah arus kas masuk atau penambahan lain suatu kesatuan dalam penyelesaian suatu kesatuan selama periode dari penyerahan atau produksi barang. Pengakuan pendapatan dalam Standar Akuntansi Keuangan PSAK No. 23 (2002:4) dikatakan bahwa pendapatan harus diukur dengan nilai wajar imbalan yang diterima atau dapat diterima.

Penulis dapat menyimpulkan beberapa hal mengenai pendapatan sebagai berikut:

a. Pendapatan secara normal terjadi setiap saat namun juga dapat terjadi pada waktu waktu tertentu

b. Pendapatan didapat melalui aktivitas penjualan barang atau jasa kepada konsumen. Hal ini juga dapat diperoleh dengan melakukan pertukaran aktiva di luar barang atau pertukaran aktiva tetap yang berdasarkan dari hasil investasi seperti bunga dan deviden.

c. Pendapatan yang memiliki karakteristik menambah atau meningkakan nilai kekayaan pemilik karena adanya penilaian Kembali atas aktiva tetap perusahaan dan aktiva yang timbul dari pembeliaan harta, investasi pemilik, pinjaman atau adanya koreksi laba rugi pada periode yang lalu, tidak dapat diakui sebagai pendapatan.

Biaya merupakan salah satu elemen perusahaan yang perlu di perhatikan untuk mencapai tujuan perusahaan sehingga mampu meraih laba sebesar mungkin dengan menggunakan biaya yang serendah mungkin. Menurut Mulyadi (2005:8), biaya merupakan pengorbanan ekonomi yang terukur dalam bentuk uang yang terjadi di masa lalu atau untuk mencapai tujuan tertentu, sedangkan dalam arti sempit, biaya merupakan pengorbanan ekonomi untuk memperoleh aktiva. Berikut adalah empat unsur berdasarkan definisi tersebut:

a. Pengorbanan sumber ekonomi

b. Uang sebagai satuan pengukuran

c. Telah terjadi atau kemungkinan akan terjadi

d. Untuk mencapai tujuan tertentu

Berdasarkan PSAK No.1 (2007:23) mengenai penyajian laporan keuangan, pengakuan biaya adalah sebagai berikut:

a. Laporan laba rugi digunakan untuk mengakui biaya jika manfaat ekonomi di masa depan mengalami penurunan yang terkait dengan penurunan aktiva atau peningkatan kewajiban yang telah terjadi serta terukur. Dalam hal ini, kenaikan kewajiban atau penurunan aktiva diakui bersamaan dengan pengakuan beban.

b. Pengakuan biaya dalam laporan laba rugi merupakan hubungan langsung antara biaya dan penghasilan yang diperoleh. Proses pengaitan biaya dan pendapatan melibatkan pengakuan penghasilan dan biaya pendapatan.

Pengakuan biaya dalam laporan laba rugi berdasarkan pada prosedur alokasi yang rasional dan sistematis. Hal ini untuk digunakan pada aktiva tetap, goodwill, paten, dan merek dagang.

\section{METODE PENELITIAN Jenis dan Sumber Data}

Data kualitatif digunakan dalam penelitian ini dengan memperhatikan karakteristik data serta keadaan dari objek yang diteliti, juga kualitasnya. Dalam penelitian ini, adalah data primer dan sekunder 
digunakan. Data primer merupakan data yang berasal dari wawancara dan pengamatan langsung di rumah sakit. Sedangkan data sekunder dikumpulkan dari data yang sudah tersedia untuk mendukung informasi yang diperoleh, yaitu bahan Pustaka, literatur, dan penelitian terdahulu.

\section{Metode Pengumpulan Data}

Untuk memperoleh data yang akurat sebagai bahan dalam pembahasan maka digunakan metode observasi dan wawancara. Dalam observasi, data dikumpulkan dengan mengadakan pengamatan langsung pada aktivitas perusahaan untuk mendapatkan gambaran nyata mengenai keadaan perusahaan. Sedangkan untuk wawancara, hal ini diadakan secara langsung kepada pimpinan atau karyawan yang diberi wewenang maupun pihak-pihak yang terkait dengan penelitian tersebut.

\section{Metode Analisis}

Metode analisis komparatif dengan melakukan perhitungan terhadap data-data dalam laporan posisi keuangan dan laporan aktivitas diaplikasikan pada jurnal ini. Hal ini didasarkan pada PSAK Nomor 23 mengenai pendapatan dalam pengakuan pendapatan yang disusun IAI dalam Pedoman Akuntansi Rumah Sakit (PARS) yang mengacu pada standar keuangan yang berhubungan yaitu PSAK No. 23 mengenai pendapatan. Serta Peraturan Mentri Keuangan Nomor 76/PMK.05/2008 tentang Pedoman Akuntansi dan Pelaporan Keuangan Badan Layanan Umum.

\section{HASIL DAN PEMBAHASAN}

Peneliti telah mengambil jurnal terkait sebagai referensi dalam melakukan penelitian yanga terukur pada Tabel 1.

Tabel 1 Penelitian Terdahulu

\begin{tabular}{|c|c|c|c|c|c|}
\hline No & $\begin{array}{c}\text { Nama } \\
\text { Peneliti }\end{array}$ & $\begin{array}{c}\text { Judul } \\
\text { Penelitian }\end{array}$ & Persamaan & Perbedaan & Kesimpulan \\
\hline 1. & $\begin{array}{l}\text { Magfirah } \\
\text { Akhmad } \\
(2006)\end{array}$ & $\begin{array}{l}\text { Audit terhadap } \\
\text { pengakuan } \\
\text { pendapatan } \\
\text { dan biaya pada } \\
\text { klinik spesialis } \\
\text { mata orbital di } \\
\text { makassar }\end{array}$ & $\begin{array}{l}\text { Informasi } \\
\text { pengakuan } \\
\text { pendapatan }\end{array}$ & $\begin{array}{l}\text { - Objek yang } \\
\text { diteliti pada } \\
\text { Klinik } \\
\text { - Membahas } \\
\text { tentang } \\
\text { pembiayaan }\end{array}$ & $\begin{array}{l}\text { Pengakuan pendapatan dan biaya } \\
\text { yang digunakan pada klinik } \\
\text { spesialis mata orbita makassar } \\
\text { adalah accrual basis, dimana } \\
\text { terjadi pada pelayanan medik } \\
\text { tunai dan kredit, jasa tunai di akui } \\
\text { dan di catat oleh perusahaan pada } \\
\text { saat terjadinya transaksi. }\end{array}$ \\
\hline 2. & $\begin{array}{l}\text { Nelly } \\
(2006)\end{array}$ & $\begin{array}{l}\text { Tinjauan } \\
\text { pengakuan } \\
\text { pendapatan jasa } \\
\text { yang disediakan } \\
\text { rumah sakit } \\
\text { didasarkan pada } \\
\text { standar } \\
\text { akuntansi } \\
\text { keuangan pada } \\
\text { rumah sakit } \\
\text { Labuang Baji di } \\
\text { Makassar }\end{array}$ & $\begin{array}{l}\text { pendapatan } \\
\text { tentang } \\
\text { standar } \\
\text { akuntansi } \\
\text { keuangan }\end{array}$ & $\begin{array}{l}\text { - Objek yang } \\
\text { diteliti pada } \\
\text { rumah sakit } \\
\text { - Membahas } \\
\text { tentang } \\
\text { pendapatan }\end{array}$ & $\begin{array}{l}\text { Pendapatan diakui dengan } \\
\text { metode accrual basis, dengan } \\
\text { mengakui pendapatan saat } \\
\text { pemberian jasa telah diselesaikan. } \\
\text { Hal ini dilakukan bersamaan } \\
\text { dengan penerimaan uang laporan } \\
\text { keuangan rumah sakit Labuang } \\
\text { Baji belum sesuai dengan standar } \\
\text { akuntansi keuangan. }\end{array}$ \\
\hline
\end{tabular}




\section{Konsep Pengakuan Pendapatan RSUP Wahidin Sudirohusodo}

Pemerintah memiliki beberapa rumah sakit, RSUP Wahidin Sudirohusodo merupakan salah satu diantaranya dimana sumbangan pemerintah merupakan sumber utama. Sumbangan tersebut pada akhirnya digunakan untuk membiayai kegiatan operasional pelayanan kesehatan untuk masyarakat. Kemudian, presentase penyelesaian digunakan sebagai metode pengakuan pendapatan, dimana pengakuan tersebut disesuaikan dengan besarnya jasa.

a. Proses Pencatatan Pendapatan Rawat Inap

Hal ini diperuntukkan bagi pasien rawat inap sebelum memasuki ruang opname untuk menentukan kelas ruang opname yang akan digunakan.

b. Saat Pengakuan Pendapatan Loket Rawat Inap

Setelah proses pemberian jasa terjadi, pendapatan baru akan diakui. Dalam hal ini, metode accrual basis di aplikasin untuk mengakui pendapatan dengan menyesuaikan besar jasa. Teruntuk pasien yang memiliki kartu ASKES, biaya pendaftaran dan Tindakan ditiadakan kecuali bagi hal hal yang tidak masuk dalam tanggungan, seperti jenis obatobat tertentu. Untuk hal ini, pasien harus melakukan penebusan.

Sistem akuntansi dalam rangka pelaporan keuangan diterapkan di RSUP Wahidin Sudirohusodo. Dalam hal ini, laporan keuangan telah disajikan secara wajar untuk hal hal yang material. Pada posisi keuangan RSUP Wahidin Sudirohusodo tanggal 31 Desmber 2017, kinerja keuangan dan arus kas untuk tahun selanjutnya telah sesuai dengan Standar Akuntansi Keuangan (SAK).

c. Pengakuan pendapatan dan biaya

1. Ketika pelayanan usai diberikan atau hak untuk menagih timbul dengan adanya barang/jasa yang diberikan pada masyarakat, pengakuan usaha dari jasa layanan (rawat inap, rawat jalan, rawat darurat) baru akan diakui.

2. Setelah pelayanan selesai diberikan atau hak penagihan yang muncul usai adanya barang/jasa diserahkan kepada masyarakat maka pengakuan usaha dari jasa layanan (rawat inap, rawat jalan, rawat darurat) baru dapat diakui.

3. Setelah hak kepemilikan barang berpindah kepada RSWS atau Ketika kas atau uang diterima oleh BLU RSWS maka saat ini pendapatan hibah baru dapat diakui.

4. Setelah penerbitan SP2D dilakukan dan dicatat sesuai dengan nilai pengeluaran bruto belanja pada SPM, maka pendapatan dari APBN baru dapat diakui.

5. Dalam proses pengakuan beban, hal ini disesuaikan dengan jumlah yang digunakan untuk operasional pelayanan rumah sakit, jumlah yang sudah dan harus dibayarkan serta jumlah estimasi atau alokasi jumlah.

d. Pendapatan Yang Diperoleh Dari Sumbangan

1. Pemerintah

2. Bahan-bahan usaha

3. Lembaga donor lokal atau lembaga nirlaba penyalur sumbangan

4. Lembaga donor internasional

5. Masyarakat

e. Saat Pengakuan Pendapatan Loket Poliklinik

Saat dimana pasien melakukan pembayaran sebelum pemeriksaan pasien dilakukan, maka pada saat itulah pengakuan pendapatan terjadi. Sehingga berdasar pada SAK, pendapatan loket poliklinik didasarkan kepada standas cash basis saat terjadi perpindahan uang cash dari pasien kepada loket poliklinik. 


\section{Konsep Pengakuan Biaya RSUP Wahidin Sudirohusodo}

RSUP Wahidin Sudirohusodo layaknya rumah sakit pada umumnya, diantara pelayanan yang ada, dua diantaranya adalah memberikan pelayanan medis khususnya di bidang kebidanan dan ginekologi. Pada dasarnya untuk melaksanakan pelayanan medis, terdapat pengorbanan sumber daya ekonomi yang dilakukan yang dihitung dalam bentuk perhitungan harga pokok. Perhitungan ini penting untuk dilakukan seakurat mungkin untuk dapat menghasilkan informasi yang bermanfaat bagi pihak manajemen dalam pengambilan keputusan. Perhitungan harga pokok dengan tingkat yang akurat ini diawali dengan melakukan kualifikasi biaya yang tepat. Berikut adalah pengorbanan sumber daya ekonomi pihak rumah sakit untuk menjalankan operasional pelayanan medis:

a. Biaya Bahan Baku

Seluruh biaya bahan dan alat sesuai jenis kegiatan dan memiliki nilai signifikan.

b. Biaya Tenaga Kerja Langsung

Upah dan gaji tenaga medis yang melayani pasien rumah sakit dalam bentuk biaya gaji dokter dan biaya gaji perawat.

c. Biaya Overhead

Biaya-biaya yang dikeluarkan atau yang teridentifikasi manfaatnya secara wajar serta tidak termasuk dalam biaya bahan baku dan biaya tenaga kerja langsung. Biaya tersebut diantaranya adalah biaya listrik, biaya alat medis habis pakai, biaya kontrak jasa kebersihan, biaya penyusutan gedung, biaya penyusutan peralatan anak, dan biaya penyusutan non-medis.

Tabel 2 Badan Layanan Umum RSUP Wahidin Sudirohusodo Makassar Laporan Posisi Keuangan Per 31 Desember 2018 (Dengan Perbandingan Angka Per 31 Desember 2017)

\begin{tabular}{|c|c|c|c|}
\hline ASET & CATATAN & $\begin{array}{c}2017 \\
\text { (Rupiah) }\end{array}$ & $\begin{array}{c}2018 \\
\text { (Rupiah) }\end{array}$ \\
\hline \multicolumn{4}{|l|}{ ASET LANCAR } \\
\hline Kas dan setara kas & $2 b, 1$ & 152.680 .945 .356 & 105.649.073.114 \\
\hline Setara kas lainnya & $2 b, 1$ & & \\
\hline Sub jumlah & & 152.680.945.356 & 105.649.073.114 \\
\hline Piutang pelayanan & $2 c, 2$ & 32.720 .148 .744 & 49.356.710.728 \\
\hline Piutang lain-lain non layanan & $2 c, 3$ & 121.932.010 & 21.711 .010 \\
\hline Persediaan & & 28.061 .430 .288 & 15.440 .346 .747 \\
\hline Uang muka & $2 d, 4$ & & \\
\hline Jumlah aset lancar & & 213.584.456.398 & 170.467 .841 .599 \\
\hline \multicolumn{4}{|l|}{ ASET TIDAK LANCAR } \\
\hline Aset Tetap & $2 e, 5$ & & \\
\hline Tanah & & 85.777 .504 .000 & 85.777 .504 .000 \\
\hline Gedung dan bangunan & & 228.921.654.211 & 228.244.448.571 \\
\hline Peralatan dan mesin & & 368.212.237.169 & 356.775 .705 .579 \\
\hline Jalan,irigrasi dan jaringan & & 25.036 .986 .135 & 24.835 .143 .810 \\
\hline Aset tetap lainnya & & & \\
\hline $\begin{array}{l}\text { Konstruksi dalam pengerjaan } \\
\text { (KDP) }\end{array}$ & & 62.187.994.925 & 27.187.995.200 \\
\hline Harga perolehan & & |36.376.467 & 722.820 .797 .160 \\
\hline Akumulasi penyusutan & & (292.664.331.745) & (280.908.704.307) \\
\hline Nilai buku aset tetap & & 477.472.044.722 & 441.912 .092 .853 \\
\hline
\end{tabular}




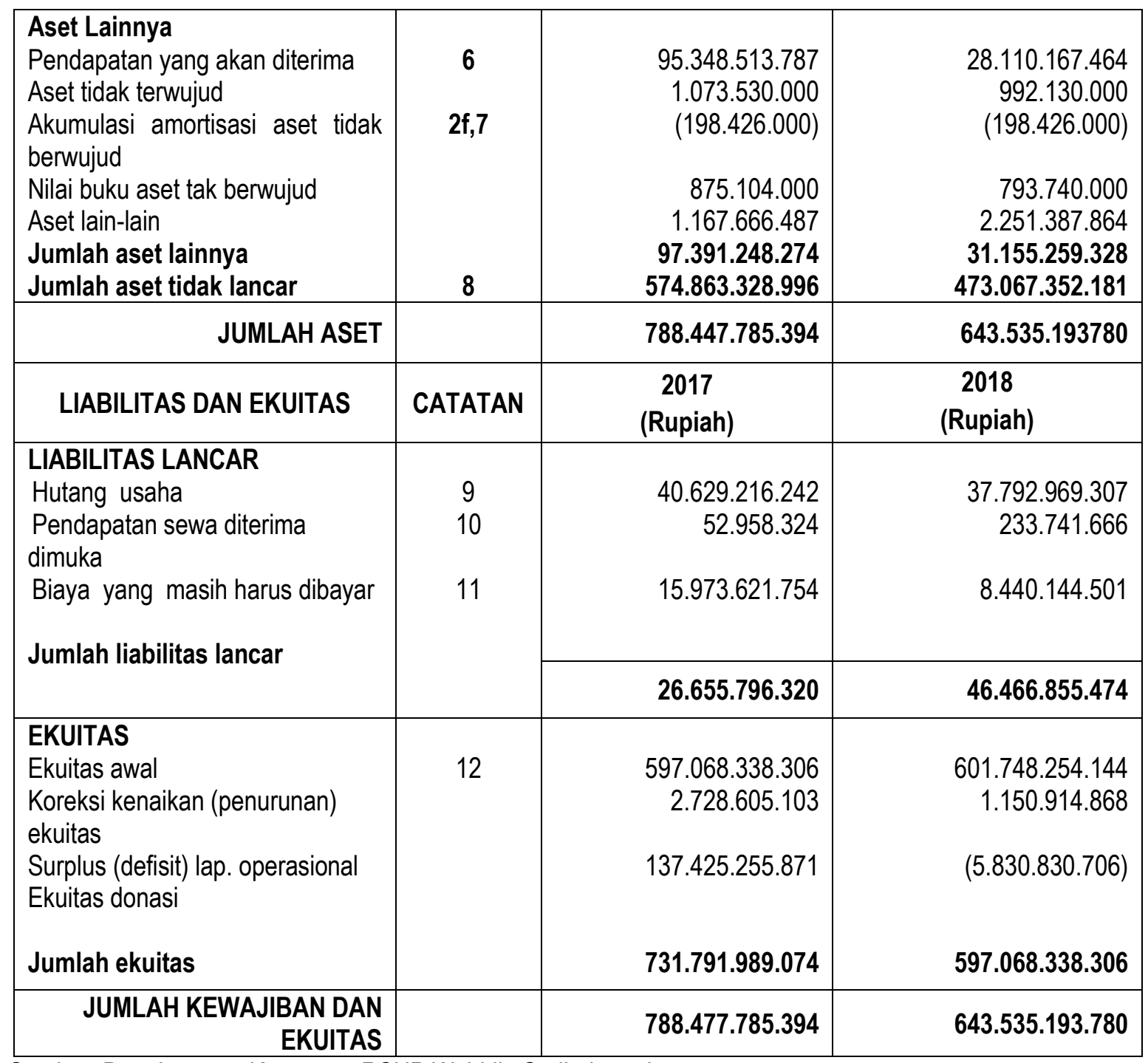

Sumber: Data Laporan Keuangan RSUP Wahidin Sudirohusodo 
Tabel 3 Badan Layanan Umum RSUP Wahidin Sudirohusodo Makassar Laporan Aktivitas Per 31 Desember 2017 (Dengan Perbandingan Angka Per 31 Desember 2018)

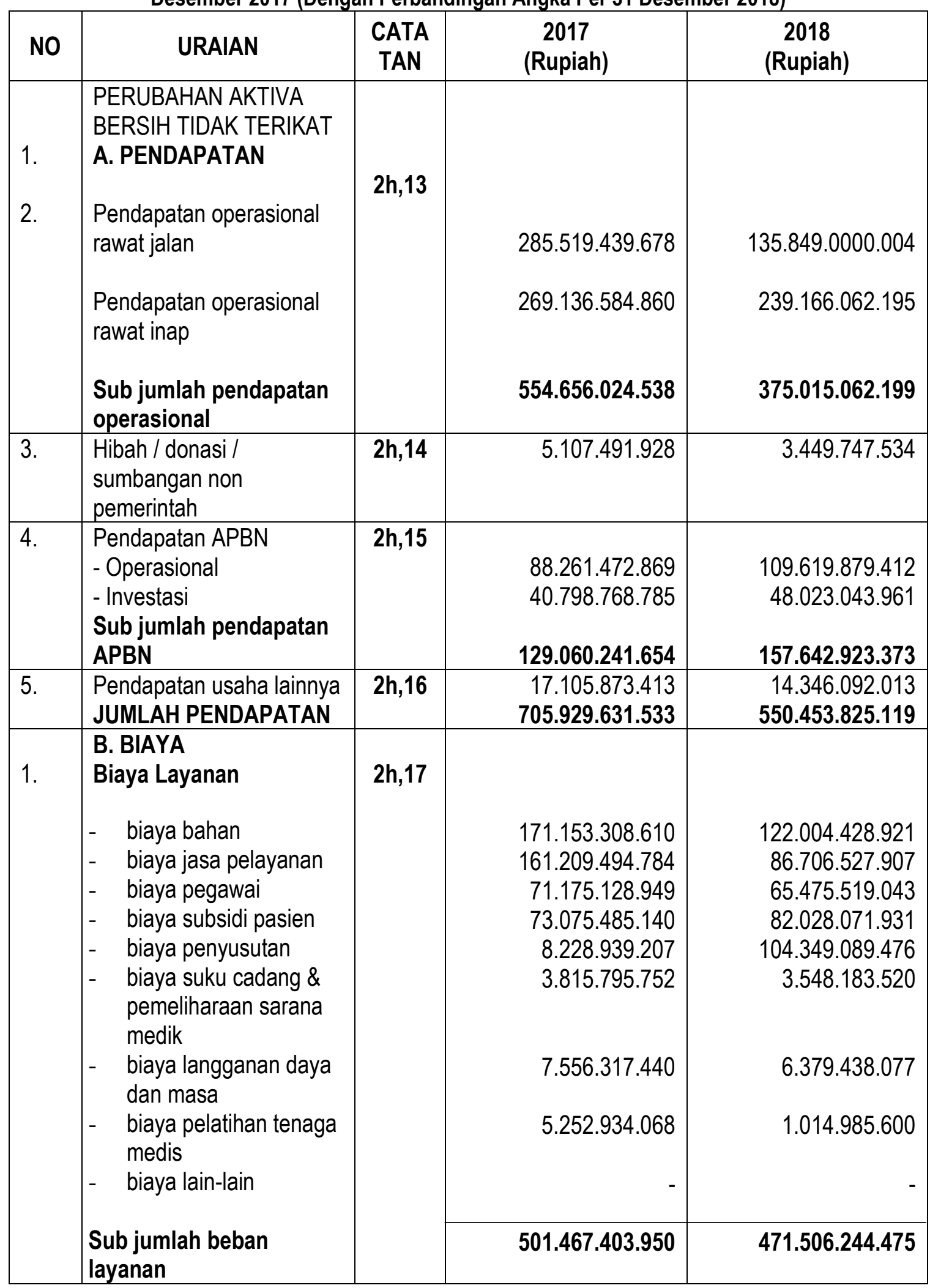




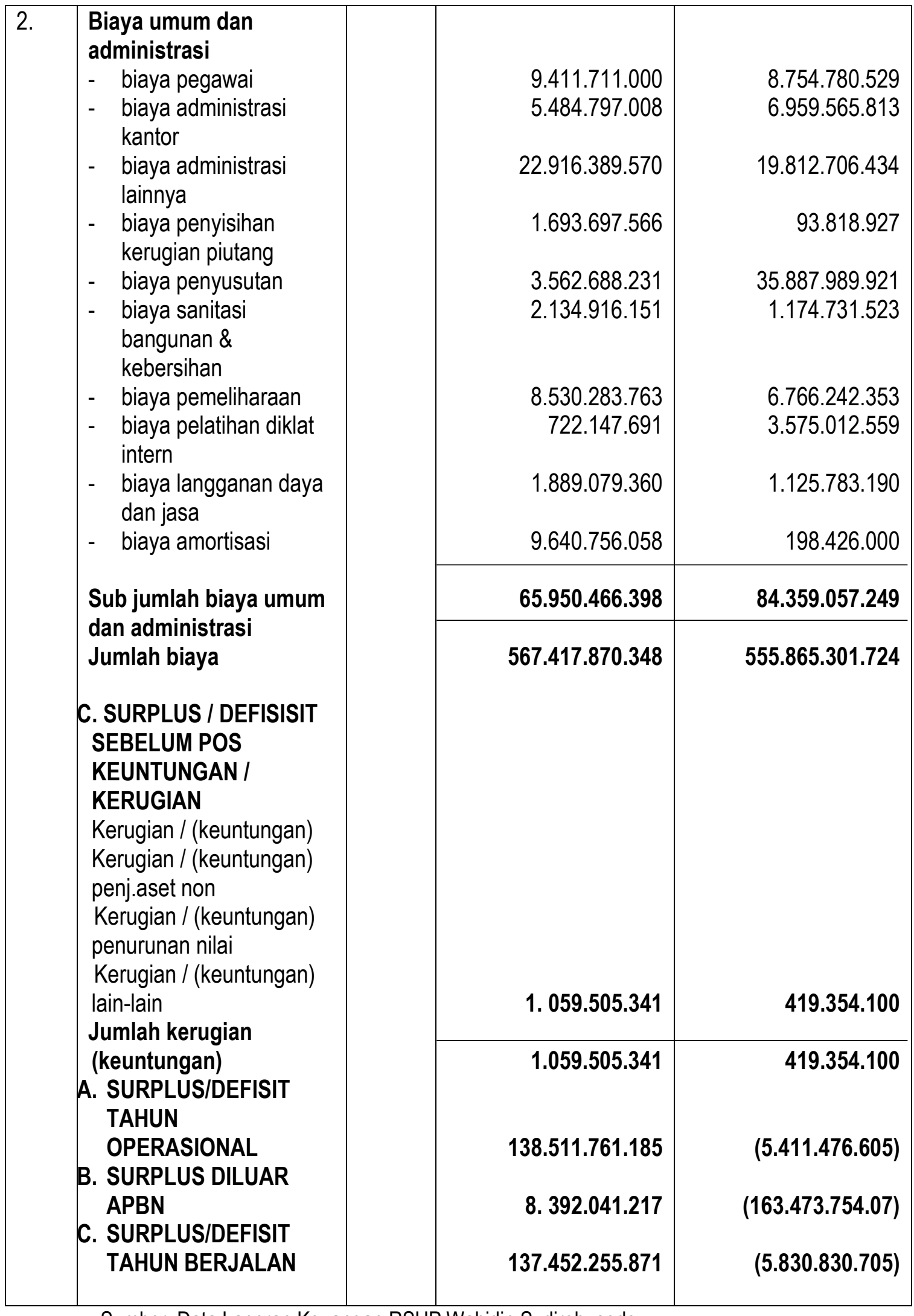

Sumber: Data Laporan Keuangan RSUP Wahidin Sudirohusodo 


\section{PENUTUP}

\section{Kesimpulan}

1. Penyusunan laporan pendapatan dan biaya bulanan diperoleh setelah adanya pencatatan penerimaan pendapatan dan biaya dari kegiatan operasional rumah sakit yang dilakukan setiap hari.

2. Metode accrual basis diterapkan untuk pengakuan pendapatan dan biaya dimana pendapatan dan biaya diakui pada saat penyelesaian pemberian jasa.

3. Sistem akuntansi telah diterapkan dalam pelaporan keuangan di RSUP Wahidin Sudirohusodo dengan baik. Hal ini terbukti dengan wajarnya laporan keuangan terlampir khusunya dalam semua hal material pada posisi keuangan BLU-RSUP Wahidin Sudirohusodo tanggal 31 Desember 2017 serta adanya kesesuaian pencatatan dengan SAK.

4. Pengakuan pendapatan dan biaya RSUP Wahidin Sudirohusodo memenuhi standar akuntansi keuangan.

\section{Saran}

1. Untuk mewujudkan pencatatan sesuai SAK yang konsisten dari waktu ke waktu, hendaknya pihak-pihak yang berkepentingan dengan hal ini untuk tetap menerapkan sistem akuntansi dalam pembuatan laporan sehingga RSUP Wahidin Sudirohusodo yang berstandar internasional.

2. SAK harus diterapkan untuk memperoleh pencatatan pendapatan dan biaya yang akurat. Hal ini penting karena mencerminkan pendapatan dan biaya yang diterima pada suatu periode tahun.

\section{DAFTAR PUSTAKA:}

Akhmad, M. (2006). Audit Terhadap Pengakuan Pendapatan Dan Biaya Pada Klinik Spesialisasi Mata Orbital Di Makassar.

Baridwan, Z. (2012). Intermediate Accounting. Edisi 7. Penerbit Fakultas Ekonomi Universitas Gajah Mada. Yogyakarta.

Harmanto. (2010). Akuntansi Keuangan Intermediate. Edisi 2. Cetakan 1. Yogyakarta.

Ikatan Akuntan Indonesia. (2002). Standar Akuntansi Keuangan. Salemba Empat: Jakarta.

Ikatan Akuntan Indonesia. (2007). Standar Akuntansi Keuangan. Salemba Empat: Jakarta.

Ikatan Akuntan Indonesia. (2009). Standar Akuntansi Keuangan Entitas Tanpa Akuntanbilitas Publik. Salemba Empat: Jakarta.

Kam, V. (2010). Accounting Theory Second Edition. Edisi 3. Badan Penerbitan Fakultas Ekonomi Universitas Gajah Mada.

Keiso dan Weygandt. (2013). Akuntansi Intermediate. Alih Bahasa Herman Wibowo. Edisi 7 Jilid 1.

Mulyadi. (2005). Sistem Akuntansi. Edisi 3. Jakarta Niswonger C, Rollin W, Carl S, dan Phillis E. Fees. 2005.

Nelly. (2006). Tinjauan Pengakuan Pendapatan Jasa Rumah Sakit Berdasarkan Standar Akuntansi Keuangan Pada Rumah Sakit Labuang Baji Di Makassar.

Peraturan Menteri Keuangan Nomor : 76/PMK.05/2008, Tanggal 23 Mei 2008 Tentang Pedoman Akuntansi Dan Pelaporan Keuangan Badan Layanan Umum.

Rudianto. (2010). Akuntansi Rumah Sakit. Erlangga: Jakarta. 